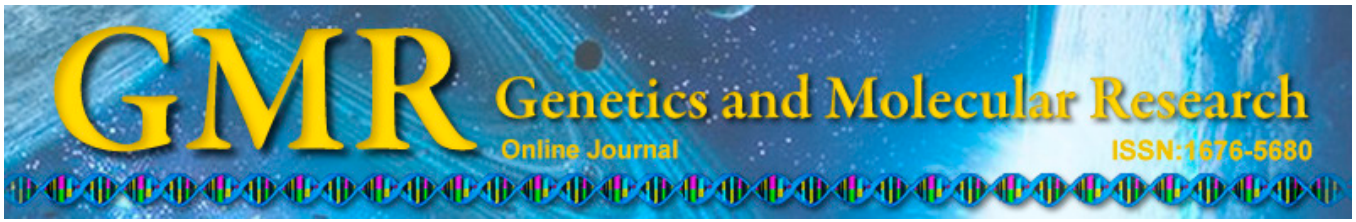

Brief Note

\title{
Variability in the cathelicidin 6 (CATHL-6) gene in Tianzhu white yak from Tibetan area in China
}

\author{
G.X. E, R.S. Na, Y.J. Zhao, L.P. Chen, X.Y. Qiu and Y.F. Huang \\ College of Animal Science and Technology, \\ Chongqing Key Laboratory of Forage \& Herbivore, \\ Chongqing Engineering Research Centre for Herbivores Resource Protection \\ and Utilization, Southwest University, Chongqing, China \\ Corresponding author: Y.F. Huang \\ E-mail: H67738337@swu.edu.cn
}

Genet. Mol. Res. 14 (2): 3129-3132 (2015)

Received September 29, 2014

Accepted January 30, 2015

Published April 10, 2015

DOI http://dx.doi.org/10.4238/2015.April.10.23

ABSTRACT. Cathelicidins are a major family of antimicrobial
peptides (AMPs), an important component of innate immune system,
playing a critical role in host defense and disease resistance in virtually
all living species. Polymorphism and functional studies on cathelicidin
of Tianzhu white yak contribute to understanding the specific innate
immune mechanism in animals living at high altitudes in comparison
to cattle and domesticated white yak. Thirty-six individuals of
Tianzhu white yak, originating from the area of three ecotypes
(Gansu in China), were investigated. The total length of the aligned
Yak cathelicidin 6 (CATHL-6) sequences was 1923 bp, including six
single nucleotide polymorphisms and one indel. Ten haplotypes were
identified, and phylogenetic analyses resolved those 10 haplotypes
in two clusters. The results indicate that the white yak originated
from two domestication sites. In addition, lack of significant pairwise
difference between sequences (Tajima's D $=0.92865, \mathrm{P}>0.10$ ) in the 
CATHL-6 region indicates absence of population size expansion in current white yak population.

Key words: Tianzhu white yak; Antimicrobial peptides; Cathelicidins (CATHL)

\section{INTRODUCTION}

The population of the Tianzhu white yak from Tibetan area of Gansu Province in China inhabits the upper slopes at $3000 \mathrm{~m}$ altitude, in the alpine steppe ecoregion. It constitutes a large and commercially important species of domestic animals from the genus Bos (Leslie Jr. and Schaller, 2009). Cathelicidins are a major family of antimicrobial peptides, an important component of innate immune system playing a critical role in host defense and disease resistance in virtually all living species (Hancock and Sahl, 2006; Takahashi et al., 2010). Polymorphisms and functional properties of cathelicidin in cattle have been the subject of many studies (Das et al., 2006; Gillenwaters et al., 2009). Identification of cathelicidin members will further our understanding of the specific innate immune mechanism in animals living at high altitude in comparison to cattle and domesticated white yak.

\section{MATERIAL AND METHODS}

Investigations were carried out in 36 individuals representing three ecotypes each represented by 12 individuals. The three ecotypes originate from three villages in the area of Gansu in China: Duoshixiangheigou village ( $\left.37^{\circ} 18.0425^{\prime} \mathrm{N} 103^{\circ} 2.1588^{\prime} \mathrm{E}\right)$, Zhaxixiulongxiang village $\left(37^{\circ} 11.7309^{\prime} \mathrm{N} 102^{\circ} 46.9758^{\prime} \mathrm{E}\right)$, and Xidatan village $\left(37^{\circ} 16.6396^{\prime} \mathrm{N} 103^{\circ} 10.1656^{\prime} \mathrm{E}\right)$. Screening for polymorphisms was performed after direct sequencing of PCR products. Information about primers see Table 1, and applied PCR protocol as following: each 50- $\mu \mathrm{L}$ PCR contained $2 \mathrm{ng}$ template DNA, $5 \mu \mathrm{L}$ 10X PCR buffer, $1.25 \mathrm{U}$ TransStart Taq DNA polymerase (TransGen Biotech, Inc., Beijing, China), $4 \mu \mathrm{L}$ dNTP $\left(2.5 \mu \mathrm{M}\right.$, including $\left.25 \mathrm{mM} \mathrm{MgCl}{ }_{2}\right), 1.5$ $\mu \mathrm{L}$ of each primer $(10 \mu \mathrm{M})$, and added $\mathrm{ddH}_{2} \mathrm{O}$ to a $50-\mu \mathrm{L}$ final volume.

\begin{tabular}{lll}
\multicolumn{2}{l}{ Table 1. PCR primer information of yak CATHL-6 region. } & \\
\hline Name & Sequences $\left(5^{\prime}-3 '\right)$ & Function \\
\hline Yak-CATHL-6F & AGGCAAGTCCACCTCACATC & Amplifies complete gene region \\
Yak-CATHL-6R & CAGAATCCAAAAGCCTGAGC & Amplifies complete gene region \\
Yak-H-2R & GTCCAGCCCTGGGCTTGGTGCCG & Used for sequencing \\
Yak-H-3R & CCTATCACCCTAGCGGTTCCTGC & Used for sequencing \\
\hline
\end{tabular}

Primers were designed using Primer3 (http://frodo.wi.mit.edu/primer3/).

The PCR procedure consisted of an initial denaturation step at $94^{\circ} \mathrm{C}$ for $5 \mathrm{~min}$, followed by 35 cycles of denaturation at $94^{\circ} \mathrm{C}$ for $1 \mathrm{~min}$, annealing at $64.5^{\circ} \mathrm{C}$ for $1 \mathrm{~min}$, and extension at $72^{\circ} \mathrm{C}$ for $2 \mathrm{~min}$, and completed by an incubation period at $72^{\circ} \mathrm{C}$ for $15 \mathrm{~min}$. Amplified DNA products were electrophoresed on 1-2\% agarose gels and sequenced on an ABI3100 DNA sequencer (Applied Biosystems, Foster City, CA, USA) following the manufacturer protocol.

Screening for haplotypes and the Tajima test were conducted by DnaSP5.10 (Librado and Rozas, 2009; http://www.ub.edu/dnasp/). Phylogenetic analyses based on neighbor-join- 
ing algorithm were carried out to determine the evolutionary relationships of the haplotypes using the MEGA 5.0 software (Tamura et al., 2011).

\section{RESULTS}

The total length of the aligned Yak CATHL- 6 sequences was 1923 bp including six single nucleotide polymorphisms ( $\mathrm{C}>\mathrm{T}$ at $695 \mathrm{bp} / 1 \mathrm{st}$ intron, $\mathrm{C}>\mathrm{T}$ at $723 \mathrm{bp} / 1 \mathrm{st}$ intron, $\mathrm{G}>\mathrm{A}$ at $765 \mathrm{bp} / 1 \mathrm{st}$ intron, $\mathrm{G}>\mathrm{A}$ at $943 \mathrm{bp} / 2 \mathrm{nd}$ intron) as well as two non-synonymous substitutions, $\mathrm{C}>\mathrm{T}$ (p.Arg $>\operatorname{Trp}$ ) at $142 \mathrm{bp} / 1$ st exon and $\mathrm{A}>\mathrm{G}$ (p.Glu $>\mathrm{Gly}$ ) at $1743 \mathrm{bp} / 4$ th exon, and one indel (G> $\triangle$ at $457 \mathrm{bp} / 1$ st intron), using the GenBank sequence KM514704 as a reference. Ten haplotypes were identified using the seven sites given above in the CATHL-6 gene of 36 white yaks, and their frequencies supplemented with the data available in the GenBank database are given in Table 2. In addition, these 10 haplotypes formed two clusters on the phylogenetic tree (Figure 1).

\begin{tabular}{|c|c|c|c|c|c|c|c|c|c|}
\hline \multirow[t]{2}{*}{ Hap_No. } & \multicolumn{7}{|c|}{ Site location (from the initial codon, ATG) } & \multirow[t]{2}{*}{ Frequency } & \multirow[t]{2}{*}{ GenBank accession No. } \\
\hline & 142 & 457 & 695 & 723 & 765 & 943 & 1743 & & \\
\hline H_1 & $\mathrm{C}$ & $\Delta$ & $\mathrm{C}$ & $\mathrm{T}$ & G & A & A & 42 & KM514696 \\
\hline $\mathrm{H}^{-} 2$ & $\mathrm{C}$ & $\mathrm{C}$ & $\mathrm{T}$ & $\mathrm{T}$ & G & A & G & 1 & KM514697 \\
\hline $\mathrm{H}^{-} 3$ & $\mathrm{~T}$ & G & $\mathrm{T}$ & $\mathrm{T}$ & A & G & A & 13 & KM514698 \\
\hline $\mathrm{H}_{-}^{-} 4$ & $\mathrm{~T}$ & $\Delta$ & $\mathrm{C}$ & $\mathrm{T}$ & G & A & A & 1 & KM514699 \\
\hline $\mathrm{H}+5$ & $\mathrm{C}$ & $\Delta$ & $\mathrm{C}$ & $\mathrm{T}$ & G & $\mathrm{G}$ & A & 1 & KM514700 \\
\hline $\mathrm{H}_{-}^{-} 6$ & $\mathrm{C}$ & G & $\mathrm{C}$ & $\mathrm{T}$ & G & $\mathrm{A}$ & A & 2 & KM514701 \\
\hline $\mathrm{H}_{-7}^{-}$ & $\mathrm{C}$ & G & $\mathrm{C}$ & $\mathrm{T}$ & G & G & $\mathrm{A}$ & 7 & KM514702 \\
\hline H_ 8 & $\mathrm{~T}$ & G & $\mathrm{C}$ & $\mathrm{T}$ & G & G & A & 1 & KM514703 \\
\hline H_9 & $\mathrm{T}$ & G & $\mathrm{C}$ & $\mathrm{T}$ & $\mathrm{A}$ & G & A & 1 & KM514704 \\
\hline H_10 & $\mathrm{C}$ & $\Delta$ & $\mathrm{C}$ & $\mathrm{C}$ & G & A & A & 3 & KM514705 \\
\hline
\end{tabular}

Hap_No.: haplotype number; ${ }^{\wedge}$ indicates deletion.

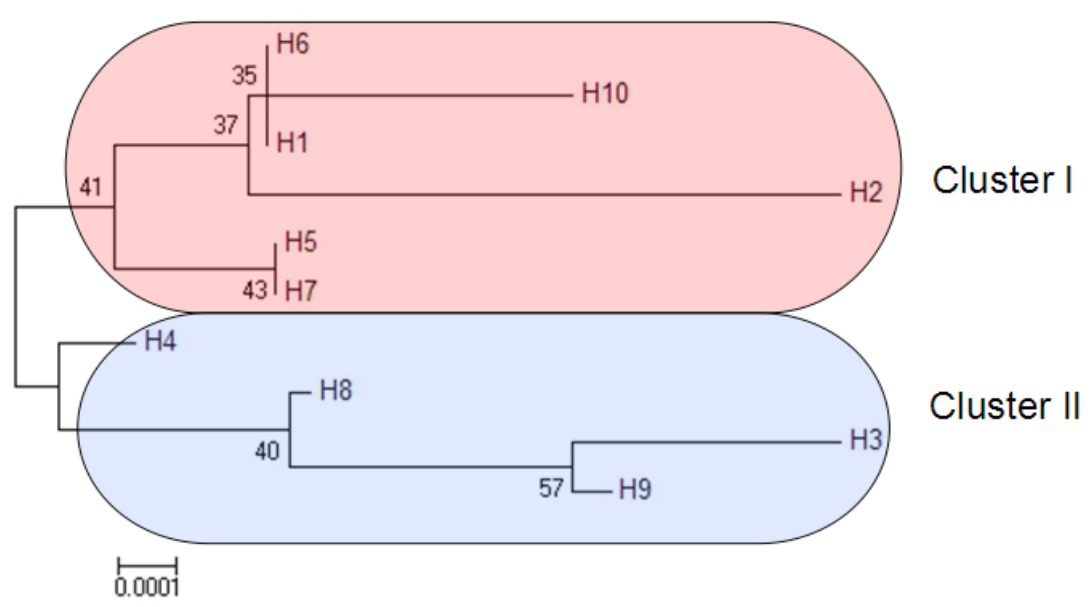

Figure 1. Neighbor-joining phylogenetic network of white yak CATHL-6 haplotypes using MEGA6.0. 
We did not detect any significant pairwise difference between the sequences (Tajima's $\mathrm{D}=0.92865, \mathrm{P}>0.10)$ in the CATHL-6 region, indicating the absence of population size expansion in the current white yak population.

\section{DISCUSSION}

The two clusters from the CATHL-6 haplotype suggest that the white yak originated from two domestication sites.

\section{ACKNOWLEDGMENTS}

Research supported by the Fundamental Research Funds for the Central Universities (\#SWU114023) and the 2013 Innovation Team Building Program in Chongqing Universities (\#KJTD201334).

\section{REFERENCES}

Das H, Sharma B and Kumar A (2006). Cloning and characterization of novel cathelicidin cDNA sequence of Bubalus bubalis homologous to Bos taurus cathelicidin-4. DNA Seq. 17: 407-414.

Gillenwaters EN, Seabury CM, Elliott JS and Womack JE (2009). Sequence analysis and polymorphism discovery in 4 members of the bovine cathelicidin gene family. J. Hered. 100: 241-245.

Hancock RE and Sahl HG (2006). Antimicrobial and host-defense peptides as new anti-infective therapeutic strategies. Nat. Biotechnol. 24: 1551-1557.

Leslie DM Jr and Schaller GB (2009). Bos grunniens and Bos mutus (Artiodactyla: Bovidae). Mamm. Species 836: 1-17.

Librado P and Rozas J (2009). DnaSP v5: a software for comprehensive analysis of DNA polymorphism data. Bioinformatics 25: 1451-1452.

Takahashi D, Shukla SK, Prakash O and Zhang G (2010). Structural determinants of host defense peptides for antimicrobial activity and target cell selectivity. Biochimie 92: 1236-1241.

Tamura K, Peterson D, Peterson N, Stecher G et al. (2011). MEGA5: molecular evolutionary genetics analysis using maximum likelihood, evolutionary distance, and maximum parsimony methods. Mol. Biol. Evol. 28: 2731-2739. 